\title{
Kształtowanie struktury napoin żeliwnych przez podwyższenie ich zdolności do grafityzacji
}

\author{
The structure forming of cast iron padding welds \\ by increasing the capacity for graphitization
}

\section{Streszczenie}

W artykule przedstawiono wyniki prac dotyczących grafityzacji zachodzącej w warunkach szybkiego chłodzenia napoin żeliwnych. Wykazano, że przez oddziaływanie na właściwości fizykochemiczne ciekłego żeliwa w jeziorku spawalniczym można efektywnie wpływać na proces grafityzacji, strukturę i właściwości uzyskanych napoin. Grafityzacji napoin sprzyja wprowadzenie do ciekłego jeziorka spawalniczego właściwych ilości podstawowych składników grafityzujących, heterogenicznych zarodków grafityzacji oraz składników obniżających napięcie powierzchniowe ciekłego metalu. Jest to sposób, który pozwala na uzyskanie metodą napawania łukowego elektrodami rurkowymi, bez podgrzania wstępnego, napoin o strukturze i właściwościach zbliżonych do właściwości żeliwa szarego.

\section{Wstęp}

Napawanie jest podstawową technologią naprawy wad odlewów żeliwa szarego. Dotyczy to głównie małych wad powstających w procesie odlewania. W większości przypadków proces ten prowadzony jest na zimno z zastosowaniem plastycznych spoiw niklowych lub stopów Ni-Fe i Ni-Cu [1]. Napoiny uzyskane w ten sposób istotnie różnią się składem chemicznym i strukturą od napawanego podłoża i nie zawsze spełniają stawiane im wymagania jakościowe. Nie są np. dopasowane kolorem do koloru żeliwa, zarówno po napawaniu, obróbce mechanicznej, jak i po korozji. Metoda ta nie spełnia również często kryteriów ekonomicznych ze względu na wysoki koszt spoiw na osnowie niklu.

W tej sytuacji nasuwa się pytanie, czy możliwe jest opracowanie metod i tanich materiałów dodatkowych,

Dr hab. inż. Andrzej Gruszczyk, Prof. PŚ - Politechnika Śląska.

\section{Abstract}

The article presents the results of the graphitization occurs under conditions of rapid cooling of cast iron padding welds. It shows that the effects on the physicochemical properties of liquid cast iron in the weld pool can effectively influence the graphitization process, structure and properties of the padding welds. Supplying the liquid weld pool appropriate quantities of basic graphitization ingredients, heterogeneous graphitization nucleus and elements which reduce the surface tension of liquid metal favour graphitization in the padding welds. It is a way that allows to produce free of defects on the structure and padding weld properties similar to the properties of cast iron padding weld by arc electrodes without pre-heating.

pozwalających na uzyskanie, przy napawaniu na zimno, napoin o właściwościach i strukturze zbliżonej do struktury napawanego materiału.

Tradycyjny sposób spawania żeliwa szarego, pozwalający uzyskać strukturę i właściwości połączeń zbliżone do właściwości materiału spawanego, polega na ograniczeniu prędkości chłodzenia ciekłego metalu i złącza w stanie stałym. W warunkach spawania jest to zabieg uciążliwy i energochłonny. Wymaga podgrzania wstępnego odlewów żeliwnych do temperatury rzędu $650^{\circ} \mathrm{C}$, wykonania połączenia w tej temperaturze i następnie bardzo wolnego chłodzenia. Jako materiały dodatkowe stosuje się pręty żeliwne (spawanie gazowe) lub elektrody otulone o składzie żeliwa szarego znieco podwyższoną zawartością podstawowych składników sprzyjających grafityzacji, tzn. węgla 3,0 $\div 3,5 \%$ i krzemu $3 \div 4 \%$ oraz dodatkami niklu $0,3 \div 0,6 \%$ i fosforu $0,2 \div 0,5 \%$ [2-5]. Jest to tzw. spawanie na gorąco. Ciekłe żeliwo jeziorka spawalniczego krzepnie wtedy w układzie stabilnym i spoina uzyskuje strukturę żeliwa szarego, a w SWC nie dochodzi do utwardzenia 
związanego z wysoką zawartością w żeliwie węgla i hartowaniem. W czasie spawania na gorąco czynnikiem decydującym o krystalizacji spoin z zarodkowaniem i wzrostem kryształów grafitu (grafityzacji) jest ograniczona szybkość stygnięcia. Nie jest to jednak jedyny sposób oddziaływania na przebieg krystalizacji żeliw.

Zdolność żeliwa do grafityzacji jest jedną z charakterystycznych cech ciekłego metalu, związaną z jego właściwościami fizykochemicznymi [2]. O jego stanie decyduje zarówno skład chemiczny, jak i parametry przebiegu procesów metalurgicznych, temperatura przegrzania, czas wytrzymania ciekłego żeliwa w wysokiej temperaturze itp. Fizykochemiczny stan ciekłego żeliwa charakteryzują jego właściwości: lepkość, napięcie powierzchniowe, napięcie międzyfazowe na granicy fazy ciekłej i grafitu, obecność uporządkowanych kompleksów atomów oraz wtrąceń niemetalicznych. Cechy te determinują skłonność żeliwa do przechłodzenia oraz do zarodkowania i wzrostu kryształów grafitu, co ma wpły na proces krystalizacji żeliwa [2]. Wykorzystuje się to w praktyce wytwarzania żeliw wysokojakościowych. W mniejszym stopniu zwraca się uwagę na te zagadnienia w czasie spawania i napawania żeliw.

$Z$ istoty procesu spawania wynikają duże prędkości chłodzenia złączy, co z powodu grafityzacji jest zjawiskiem bardzo niekorzystnym. Z drugiej strony procesy spawalnicze stwarzają niewykorzystane do tej pory możliwości oddziaływania na właściwości fizykochemiczne ciekłego żeliwa w jeziorku spawalniczym, co sprzyja grafityzacji. Wiąże się to z wyborem rodzaju i ustaleniem w spoinach optymalnej z punktu widzenia grafityzacji zawartości:

- podstawowych składników stopowych sprzyjających grafityzacji,

- modyfikatorów grafityzujących,

- heterogenicznych zarodków grafityzacji,

- składników wpływających na powierzchniowe właściwości ciekłego metalu.

\section{Przebieg badań}

Podstawowe badania związane z doborem optymalnych właściwości fizykochemicznych stopiw do napawania żeliwa szarego wykonano z użyciem otulonych elektrod rurkowych. Mają one budowę podobną do otulonych, ale ich rdzeń elektrody stanowi cienkościenna rurka stalowa o średnicy $6 \div 12 \mathrm{~mm}$ i długości $350 \div 500 \mathrm{~mm}$, wypełniona głównie stopowymi składnikami metalicznymi. Zewnętrzna powierzchnia rurek pokryta jest otuliną wytwarzaną najczęściej metodą maczania (rys. 1). Ze względu na znaczny udział proszkowego wypełnienia w ogólnej masie elektrod, otulone elektrody rurkowe zapewniają możliwość uzyskania jednowarstwowych napoin o bardzo wysokiej zawartości składników stopowych. Stabilne jarzenie się łuku elektrycznego uzyskuje się przy niższych wartościach prądu niż przy napawaniu elektrodami otulonymi tej samej grubości.

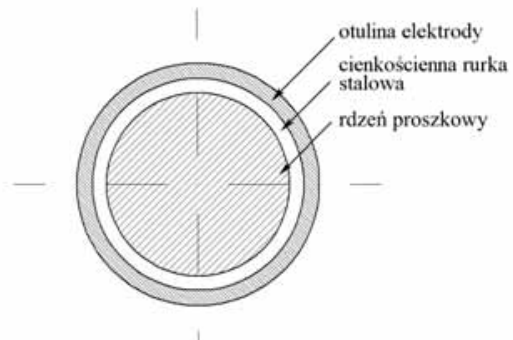

Rys. 1. Otulona elektroda rurkowa

Fig. 1. Tube covered electrode

Ogranicza to głębokość wtopienia i ogólną ilość ciepła wprowadzoną do elementu napawanego. Sprzyja też efektywnemu wykorzystaniu składników stopowych i obniżeniu poziomu naprężeń. Otulone elektrody rurkowe stosowane były do tej pory tylko do napawania utwardzającego [6, 7].

Próby napawania prowadzono wykonanymi w warunkach laboratoryjnych otulonymi elektrodami rurkowymi o średnicy $9 \mathrm{~mm}$ z otuliną zasadową lub rutylową grubości ok. $2 \mathrm{~mm}$ oraz elektrodami rurkowymi bez otuliny w atmosferach ochronnych i bez osłony gazowej $[8,9]$. Procentowy udział masy proszkowych składników rdzenia do masy elektrody bez otu-

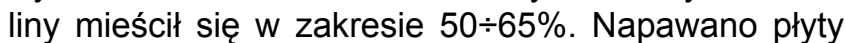
z żeliwa szarego o grubości 8, 22 i 34 mm bez podgrzania wstępnego i z podgrzaniem do temperatury $300^{\circ} \mathrm{C}$. $\mathrm{Na}$ powierzchni płyt wykonywano napoiny punktowe, stapiając każdorazowo ok. $100 \mathrm{~mm}$ elektrody, prądem stałym o natężeniu $180 \div 260 \mathrm{~A},(+)$ na elektrodzie. Wykonano również napoiny naprawcze symulowanych wad powierzchniowych. Oceniano stabilność jarzenia łuku elektrycznego, formowanie napoin, sposób stapiania elektrody, liczbę rozprysków itp. Uzyskane napoiny poddano badaniom metalograficznym makro i mikroskopowym oraz pomiarom twardości. Na właściwości fizykochemiczne ciekłego metalu jeziorka spawalniczego wpływano przez:

- zmiany zawartości podstawowych składników stopowych sprzyjających grafityzacji, tzn. węgla i krzemu,

- wprowadzenie do ciekłego metalu modyfikatora w postaci żelazostopu Fe-Ca-Si,

- wprowadzenie do ciekłego metalu heterogenicznych zarodków krystalizacji,

- zmianę zawartości składników aktywnych powierzchniowo.

\section{Wpływ węgla i krzemu na strukturę napoin i właściwości spawalnicze otulonych elektrod rurkowych}

Węgiel i krzem jako podstawowe składniki stopowe sprzyjające grafityzacji żeliw szarych stanowiły znaczną część proszkowego rdzenia otulonych elektrod rurkowych. Wstępne badania polegały na 

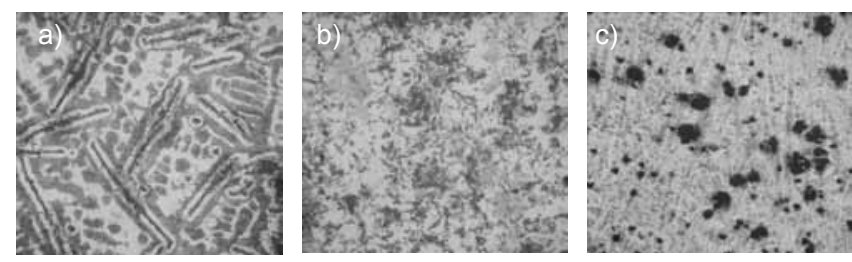

Rys. 2. Typowe mikrostruktury napoin wstępnej serii badań: a) żeliwo połowiczne z grafitem płatkowym, HV30 $=300$, pow. 200x, Nital, b) żeliwo połowiczne z grafitem drobnym, HV30 = 290, pow. 200x, Nital, c) żeliwo połowiczne z grafitem kulkowym, HV30 = 724, pow. 50x, Nital

Fig. 2. Typical microstructures of padding welds in preliminary series of research: a) mottled cast iron with flake graphite, HV30 $=300$, magn. 200x, Nital; b) mottled cast iron with fine graphite, HV30 = 290, magn. 200x, Nital, c) mottled cast iron with modular graphite HV30 = 300, magn. 50x, Nital
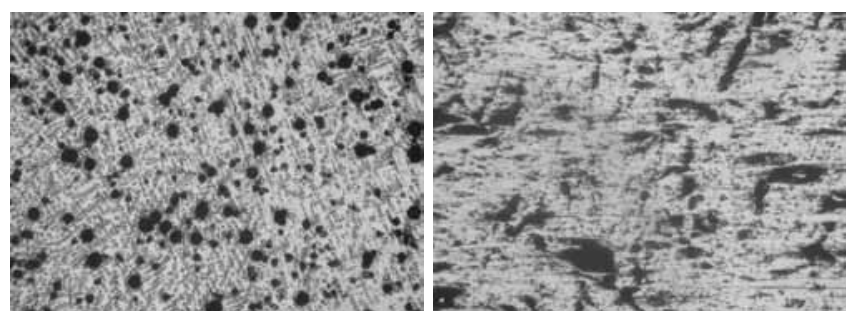

Rys. 3. Struktura napoiny wyko- Rys. 4. Postać grafitu w napoinie nanej otuloną elektrodą rurkową wykonanej elektrodą zawierającą z wysoką zawartością Fe-Ca-Si, dodatki spełniające funkcję heteHV30 $=680$, pow. 50x, Nital rogenicznych zarodków grafityFig. 3. Structure of padding weld zacji, $H V 30=229$, pow. $50 x$ made using tube covered electro- Fig. 4. Form of graphite in the de with $\mathrm{Fe}-\mathrm{Ca}-\mathrm{Si}, \mathrm{HV} 30=680$, padding weld made using elecmagn. 50x, Nital trode with additives containing heterogeneous graphitization nucleus, $\mathrm{HV} 30=229$, magn. $50 x$

\section{Wpływ heterogenicznych zarodków grafityzacji na strukturę napoin} tymi elektrodami. Próby napawania płyt żeliwnych o grubości $22 \mathrm{~mm}$ prowadzono elektrodami $\mathrm{z}$ otuliną zasadowa bez podgrzania wstępnego. Stwierdzono, że ze wzrostem zawartości grafitu w rdzeniu otulonych elektrod rurkowych pogarszają się ich właściwości spawalnicze. Wynikało to z tego, że proszkowy rdzeń z wysoką zawartością grafitu stapiał się wolniej niż stalowa rurka. Prowadziło to do zakłóceń jarzenia się łuku elektrycznego, nieprawidłowego formowania napoin i rozprysków (rys. 5a). llość grafitu i krzemu oraz proporcje między tymi składnikami w proszkowym rdzeniu elektrod istotnie wpływały również na twardość i strukturę wykonanych napoin. Typowe mikrostruktury napoin uzyskanych $w$ tej serii badań przedstawiono na rysunku 2.

\section{Wpływ modyfikatorów grafityzujących na strukturę napoin}

Podstawowym modyfikatorem grafityzującym, stosowanym w badaniach, był wapń w postaci żelazostopu Fe-Ca-Si. Niewielkie, zmienne ilości tego składnika dodawano do proszkowych wypełnień elektrod. Wykonano cztery serie elektrod testowych i przeprowadzono próby napawania na zimno. Badano mikrostrukturę i twardość uzyskanych napoin. W zakresie stosowanych w badaniach stężeń Fe-Ca-Si nie stwierdzono pozytywnego wpływu Ca na postać i ilość tworzącego się w napoinach grafitu. Wyższe zawartości Fe-Ca-Si wyraźnie pogarszały strukturę napoin i podwyższały ich twardość (rys. 3). do proszkowych rdzeni elektrod w postaci proszków. Dla części wymienionych składników zmieniano również ich granulację. Stwierdzono, że efektywność oddziaływania wprowadzonych dodatków jako zarodków krystalizacji jest różna i w dużym stopniu zależy od wielkości cząstek wprowadzanych do ciekłej kąpieli jeziorka spawalniczego. Korzystne oddziaływanie heterogenicznych zarodków grafityzacji polega na tworzeniu się znacznej ilości drobnych wydzieleń grafitu bez podwyższania twardości osnowy (rys. 4).

\section{Wpływ powierzchniowych właściwości ciekłego metalu na przebieg napawania i strukturę napoin}

$\mathrm{Na}$ napięcie powierzchniowe ciekłego metalu w procesie napawania otulonymi elektrodami rurkowymi wpływano przez zmiany składu chemicznego proszkowych rdzeni elektrod i otulin oraz dobór odpowiednich atmosfer gazowych w czasie napawania elektrodami rurkowymi bez otuliny. Stwierdzono, że wysokie napięcie ciekłego metalu pogarsza nie tylko formowanie i odgazowanie napoin, ale sprzyja również sferoidyzacji grafitu i krzepnięciu osnowy w układzie metastabilnym, co znacznie podwyższa ich twardość (rys. 3). Zastosowanie środków obniżających napięcie powierzchniowe ciekłego metalu poprawiło właściwości spawalnicze elektrod oraz ułatwiło napawanie i formowanie napoin. Umożliwiło również uzyskanie napoin
Heterogeniczne zarodki grafityzacji wprowadzano 

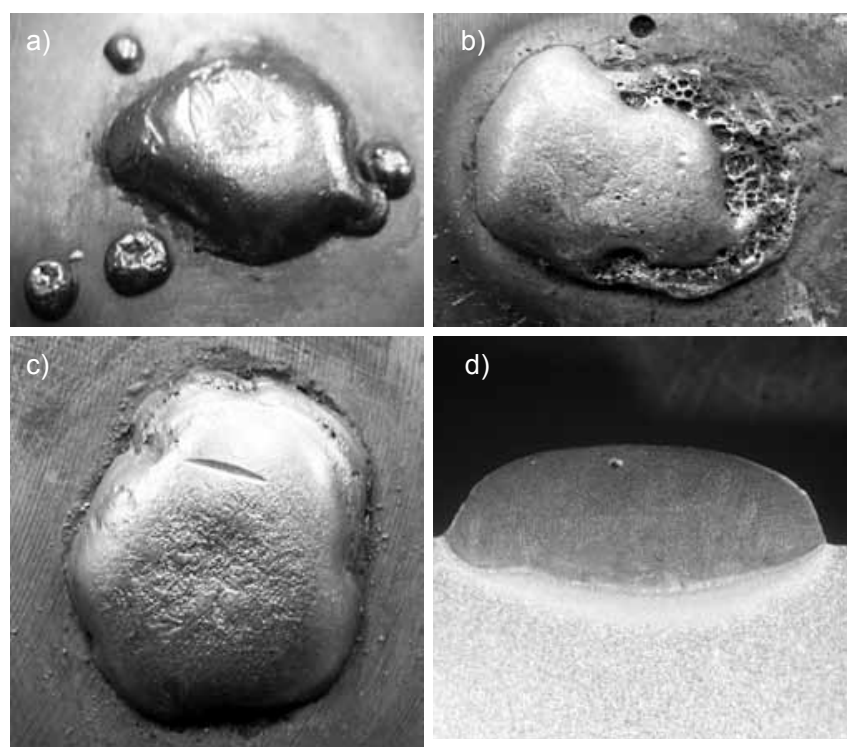

Rys. 5. Napoiny punktowe wykonane otulonymi elektrodami rurkowymi: a) nieprawidłowe formowanie napoiny, b) napoina wykonana elektrodą rurkową bez otuliny w powietrzu, c) napoina wykonana otuloną elektrodą rurkową z właściwie dobranym składem chemicznym rdzenia i zastosowaniem środków obniżających napięcie powierzchniowe ciekłego metalu, HV30 = 212, d) makrostruktura napoiny punktowej

Fig. 5. Point padding weld made using tube covered electrode: a) incorrect shape of padding weld, b) padding weld made using tube electrode without covering in the air, c) padding weld made using tube covered electrode with correct chemical composition and with the use of surface tension decreasing medium of liquid metal, $\mathrm{HV} 30=212, \mathrm{~d}$ ) macrostructure of point padding weld
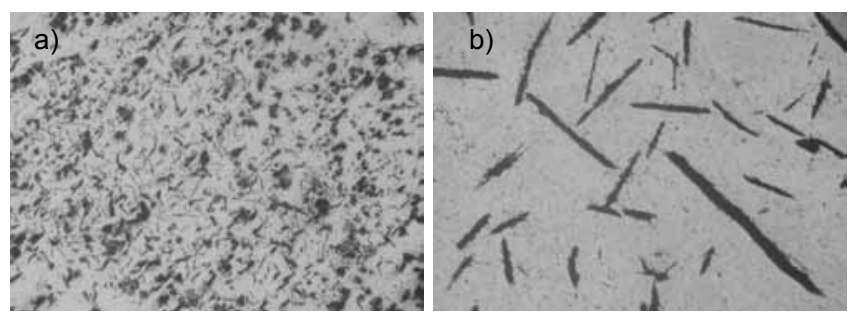

Rys. 6. Wpływ otuliny na postać grafitu i twardość napoin wykonanych elektrodami rurkowymi: a) elektroda otulona zasadowa, grafit punktowy i płatkowy, HV30 = 212, zgład nietrawiony, b) elektroda bez otuliny, grafit płatkowy, HV30 $=314$, pow. 100x, zgład nietrawiony

Fig. 6. The influence of covering on the graphite shape and hardness of padding welds made using tube electrodes: a) basic covered electrode, fine and flake graphite, HV30 $=212$, non-etching, b) electrode without covering, flake graphite, HV30 $=314$, magn 100x, non-etching

o strukturze i właściwościach zbliżonych do właściwości żeliwa szarego. Na rysunku 5c przedstawiono wynik napawania na zimno płyty żeliwnej o grubości $22 \mathrm{~mm}$ z zastosowaniem środków obniżających napięcie powierzchniowe ciekłego metalu. Średnia twardość na przeszlifowanej powierzchni napoiny kształtowała się na poziomie 212 HV30.

Istotny wpływ na przebieg napawania, właściwości ciekłego metalu i strukturę uzyskanych napoin miał również rodzaj i skład chemiczny otulin elektrod rurkowych. Próby napawania otulonymi elektrodami rurkowymi rutylowymi i zasadowymi wykazały, że znacznie lepszymi właściwościami charakteryzowały się elektrody z otuliną zasadową. Dla porównania wykonano również próby napawania elektrodami rurkowymi bez otuliny i bez osłony gazowej (rys. 5b). Różnice struktury i twardości napoin wykonanych otuloną elektrodą rurkową z otuliną zasadową i elektrodą rurkową bez otuliny w atmosferze powietrza przedstawiono na rysunku 6.

\section{Naprawa powierzchniowych wad odlewniczych z zastosowaniem otulonych elektrod rurkowych}

Napawanie żeliwa szarego na zimno wiąże się z utwardzeniem SWC wynikającym z hartowania i tworzenia się warstwy zabielonej. Istotny wpływ na twardość SWC płyt napawanych bez podgrzania wstępnego miała ich grubość. Przy napawaniu płyt o grubości $34 \mathrm{~mm}$ utwardzenie w SWC osiągnęło 700 HV1. Przy napawaniu bez podgrzania wstępnego płyty o grubości $8 \mathrm{~mm}$ maksymalna twardość SWC niewiele przekroczyła 300 HV1 (rys. 7).

Mimo utwardzenia SWC przy napawaniu na zimno ani w napoinach, ani w obszarach przyległych do napoin wykazujących korzystną strukturę i niską twardość nie zaobserwowano pęknięć (rys. 5d). Utwardzenie SWC utrudnia jednak obróbkę skrawaniem naprawionego obszaru odlewu, dlatego próby naprawy wad odlewniczych prowadzono bez podgrzania i z podgrzaniem wstępnym do temperatury $300^{\circ} \mathrm{C}$.

Do napawania wytypowano odlewy żeliwne o strukturze żeliwa szarego. Na powierzchni napawanych elementów wykonano symulacyjnie obróbką skrawaniem różnej wielkości wady powierzchni. Próby te wykazały, że istotny wpływ na przebieg napawania i jakość uzy-

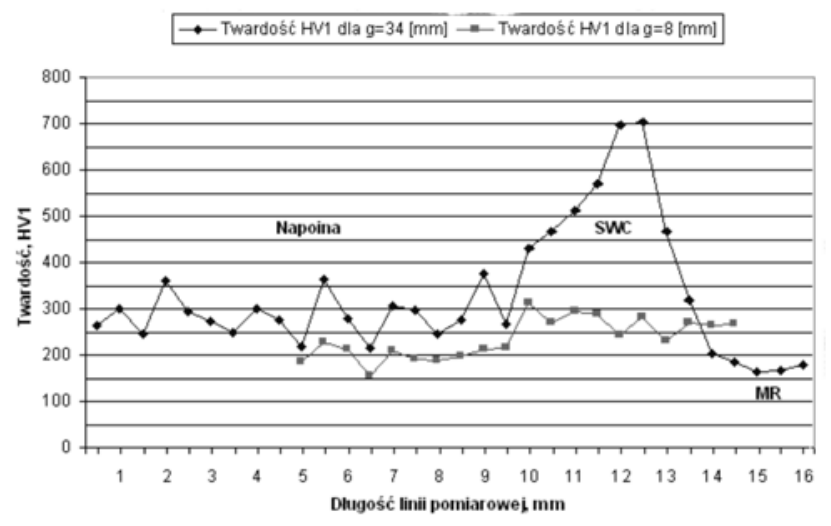

Rys. 7. Rozkład twardości HV1 w napoinie, SWC i materiale rodzimym po napawaniu otulonymi elektrodami rurkowymi płyt żeliwnych o grubości 8 i $34 \mathrm{~mm}$ bez podgrzania wstępnego

Fig. 7. Hardness distribution in the padding weld, HAZ and base material after tube electrodes surfacing of 8 and $34 \mathrm{~mm}$ cast iron plates without preheating 


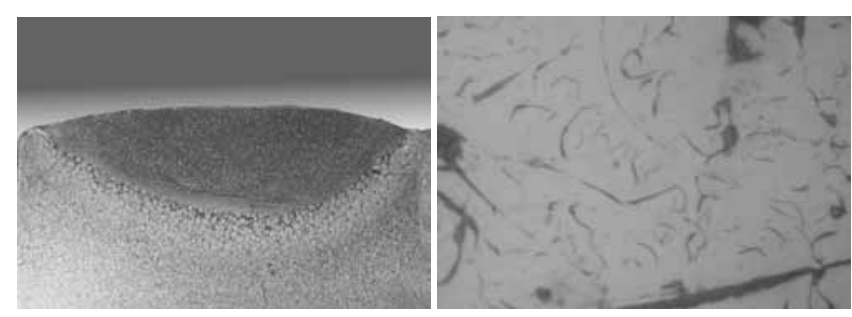

Rys. 8. Makrostruktura odlewu w miejscu usunięcia wady powierzchniowej metodą napawania z podgrzaniem wstępnym do temperatury $300^{\circ} \mathrm{C}$ (a) oraz postać grafitu w napoinie, pow. 500x (b). Twardość na powierzchni napoiny HV30 $=239$

Fig. 8. Macrostructure of cast in the place of defect remove using the surfacing method and preheated up to $300^{\circ} \mathrm{C}$ (a) and the form of graphite in the padding weld, magn. $500 x$ (b). Hardness of the surface of padding weld is HV30 $=239$

skanych napoin ma napawane podłoże. Niepowodzeniem zakończyły się próby usuwania wad odlewów żeliwnych o niskiej czystości metalurgicznej. Dotyczyło to np. prób napawania naddatków technologicznych (nadlewów), gdzie duża ilość gazów zawartych w napawanym podłożu powodowała burzenie się ciekłego metalu w jeziorku spawalniczym. W napoinach występowały wady w postaci porów i pęcherzy oraz zauważono tendencję do oddzielania się napoin od napawanego podłoża.

Typowy wynik naprawy odlewu żeliwnego o grubości ścianki $25 \mathrm{~mm} \mathrm{z}$ podgrzaniem wstępnym do $300^{\circ} \mathrm{C}$, przedstawiono na rysunku 8 . Podgrzanie wstępne ułatwiało formowanie napoin w podolnej pozycji napawania, jednak w niektórych przypadkach, towarzyszący podgrzaniu wysoki stopień wymieszania stopiwa z podłożem, wpływał niekorzystnie na strukturę i twardość napoin.

\section{Podsumowanie}

Próby napawania otulonymi elektrodami rurkowymi wykazały, że składnikiem istotnie wpływającym na właściwości spawalnicze i właściwości napoin wykonanych otulonymi elektrodami rurkowymi jest grafit. Wraz ze wzrostem jego ilości w proszkowym rdzeniu elektrod pogarszają się ich właściwości spawalnicze (rys. 5a). Zmieniając ilość i proporcje między zawartością grafitu i krzemu w proszkowych rdzeniach elektrod, można uzyskać napoiny różniące się znacznie ilością i kształtem wydzielonego grafitu. Napoiny wykonane elektrodami z różną zawartością krzemu i grafitu miały strukturę żeliwa połowicznego, a twardość ich zmieniała się w zakresie 290 $\div 724$ HV30 (rys. 2). Stwierdzono, że z występowaniem grafitu kulkowego wiąże się zwykle krzepnięcie osnowy napoiny w układzie metastabilnym i znaczne utwardzenie napoin (rys. 2c).
Nie powiodły się próby wprowadzenia do ciekłego metalu jeziorka spawalniczego modyfikatora grafityzującego w postaci Fe-Ca-Si. Modyfikatory swą skuteczność w żeliwie wykazują przy śladowych zawartościach. W warunkach napawania otulonymi elektrodami rurkowymi trudno było precyzyjnie ustalić zawartości modyfikatora dostosowane do składu chemicznego ciekłego jeziorka żeliwa. W przeprowadzonych próbach zawartość wapnia była zbyt wysoka, a wpływa on na właściwości żeliwa jak zwykły składnik stopowy. Doprowadziło to do pogorszenia właściwości napoin (rys. 3). Znacznie łatwiejsze i praktyczniejsze jest wprowadzenie do jeziorka ciekłego metalu heterogenicznych zarodków grafityzacji. Stosowane w badaniach materiały wykazywały różną skuteczność oddziaływania jako zarodki grafityzacji. Część z nich pogarszała właściwości napoin. Pozostałe korzystnie wpływały na postać i ilość wydzielonego w napoinach grafitu (rys. 4).

Ważnym czynnikiem wpływającym na właściwości spawalnicze elektrod oraz przebieg grafityzacji i twardość napoin wykonanych otulonymi elektrodami rurkowymi okazało się napięcie powierzchniowe ciekłego metalu jeziorka spawalniczego. Na wartość napięcia powierzchniowego ciekłego metalu można wpływać zarówno przez zmiany składu chemicznego proszkowego rdzenia elektrody otuliny, jak i przez zastosowanie specjalnych atmosfer gazowych, w których odbywa się napawanie elektrodami rurkowymi bez otulin. Istotny wpływ na właściwości elektrod wywierały również stosowane w badaniach otuliny. Gorszymi właściwościami spawalniczymi charakteryzowały się elektrody z otuliną rutylową. Napoiny wykonane tymi elektrodami wykazywały skłonność do porowatości. Niewielka porowatość w napoinach wykonanych elektrodami zasadowymi występowała sporadycznie (rys. 5d). Stosunkowo niewielkiej grubości otuliny zasadowe skutecznie chroniły ciekły metal przed dostępem atmosfery. Napawanie otulonymi elektrodami rurkowymi bez otuliny w atmosferze powietrza ze względu na znaczna porowatość i utwardzenie napoin było niemożliwe (rys. 5b, 6b). Skład chemiczny zastosowanych w badaniach otulin zasadowych wpływał również znacznie na strukturę i twardość napoin wykonanych otulonymi elektrodami rurkowymi (rys. 6).

Napawanie otulonymi elektrodami rurkowymi grubościennych elementów żeliwnych bez podgrzania wstępnego prowadzi do utwardzenia SWC związanego z tworzeniem wąskiej strefy zabielonej i hartowaniem. Maksymalna twardość SWC osiąga wartości rzędu 700 HV1. Szerokość strefy o maksymalnej twardości jest niewielka i jeżeli napoina ma odpowiednią strukturę i niską twardość, w obszarze napawanym nie pojawiają się pęknięcia. Obniżenie grubości ścianki odlewów żeliwnych napawanych na zimno wpływa korzystnie na twardość SWC i napoin (rys. 7). 


\section{Wnioski}

Korzystną strukturę i właściwości napoin żeliwnych wykonanych bez podgrzania wstępnego uzyskać można podwyższając zdolności do grafityzacji metalu jeziorka spawalniczego przez:

- właściwy dobór ilości i proporcji między podstawowymi składnikami stopowymi żeliwa sprzyjającymi grafityzacji,

- wprowadzenie do jeziorka ciekłego metalu heterogenicznych zarodków grafityzacji,

- zastosowanie środków obniżających napięcie powierzchniowe ciekłego metalu.

Elektrody rurkowe pozwalają na uzyskanie w czasie napawania łukowego żeliwa szarego bez podgrzania wstępnego - pozbawionych wad napoin o strukturze i właściwościach zbliżonych do właściwości napawanego podłoża.

\section{Literatura}

[1] Klimpel A.: Napawanie naprawcze odlewów żeliwnych. Przegląd Spawalnictwa, 2-3/2002.

[2] Podrzucki C., Kalata C.: Metalurgia i odlewnictwo żeliwa. „Śląsk”, Katowice 1978.

[3] Poradnik Inżyniera, Odlewnictwo. WNT, Warszawa 1986.

[4] Sprawocznik, Svarka w Maszinostrojenii, T. 4. Maszinostrojenie, Moskwa 1978.

[5] Ciszewski G.: Własności wytrzymałościowe i plastyczne złączy otrzymanych w wyniku spawania żeliwa z grafitem płatkowym i sferoidalnym z zastosowaniem elektrod prętowych. Biuletyn Instytutu Spawalnictwa, 2/1996.

[6] Klimpel A., Gruszczyk A., Luksa K., Szymański A.: Otulone elektrody rurkowe do napawania. Przegląd Spawalnictwa, 4/1995.

[7] Menown D.: Chromium carbide: Welding against wear Welding and Metal Fabrication, 7-8/1984.

[8] Patent RP Nr 202157, Elektroda otulona rurkowa do napawania żeliwa.

[9] Zgłoszenie patentowe P385396, Rdzeń proszkowy elektrod rurkowych i drutów proszkowych do spawania i napawania żeliwa.

\section{Nowości techniczne}

\section{FARO wprowadza najbardziej innowacyjne na świecie ramię pomiarowe: FARO Edge}

Firma FARO Technologies Inc., światowy dostawca przenośnych systemów pomiarowych oraz rozwiązań do obróbki obrazu, wprowadziła na rynek zaawansowane i nowoczesne ramię pomiarowe FARO Edge oraz najnowszej generacji głowicę skanujacca Laser Line Probe.

FARO Edge jest przenośnym ramieniem pomiarowym, które umożliwia weryfikację jakości wyrobów przez wykonywanie kontroli, certyfikacji narzędzi, analiz porównawczych części z plikami konstrukcyjnymi (CAD-to-part) oraz inżynierii odwrotnej przy użyciu głowic pomiarowych i bezstykowego skanowania laserowego.

FARO Edge pozwala udoskonalić procesy produkcji, kontroli jakości i inżynierii odwrotnej dzięki szybkiemu weryfikowaniu lub skanowaniu części z zachowaniem dużej pewności i dokładności. Nowe ramię pomiarowe zwiększa również komfort obsługi, ponieważ jest bardziej wydajne, przenośne i niezawodne.

Nowe ramię pomiarowe FARO Edge udostępnia pierwszy w historii osobisty asystent pomiarowy. Dzięki wbudowanemu ekranowi dotykowemu i systemowi operacyjnemu stanowi rewolucję na obszarze przenośnych urządzeń pomiarowych, umożliwiając niezależne prowadzenie podstawowych pomiarów. Do wykonywania szybkich, prostych kontroli wymiarów nie potrzeba już laptopa, a działanie systemu można zoptymalizować przy użyciu wbudowanych procedur diagnostycznych.

Ramię Edge, dostępne w trzech wielkościach roboczych i konfiguracji 7-osiowej, sprawdza się jako przenośne urzadzenie pomiarowe, eliminując konieczność ustalania długości odpowiedniej dla danego zlecenia. Siedem osi obrotu gwarantuje maksymalną elastyczność obsługi urządzenia.

\section{Dodatkowe obszary usprawnień}

Udoskonalone możliwości połączeń - Bluetooth, WiFi, USB i Ethernet; możliwość zarządzania wieloma urządzeniami za pośrednictwem sieci.

Technologia inteligentnych czujników - udoskonalone czujniki ostrzegają przed nadmiernym obciążeniem, wprowadzają poprawki uwzględniające zmiany temperatury i wykrywają możliwe problemy z konfiguracją.

Ergonomia - lepszy rozkład masy i równowaga zmniejszają naprężenia i ułatwiają obsługę. Opatentowana wewnętrzna przeciwwaga zapewnia wygodne, bezstresowe użytkowanie.

Port wielofunkcyjny - łatwa wymiana akcesoriów, specjalny uchwyt ułatwiający wymianę, rozszerzalność.

Najnowsza głowica skanująca FARO Laser Line Probe umożliwia wykonywanie pomiarów bezstykowych. Szerszy pasek laserowy znacznie zwiększa zasięg skanowania bez szkody dla dokładności, a dzięki zmiennej szybkości rejestrowania można uzyskiwać ponad 45.tys. punktów na sekundę z zachowaniem wyjątkowej prędkości i rozdzielczości skanowanych obiektów.

Dzięki wielofunkcyjnemu, szybkiemu w obsłudze portowi ramienia Edge, głowica skanująca LLP integruje się z urządzeniem, stając się od razu jego częścią. Mniejsza masa, kompaktowe wymiary i dyskretny wygląd powodują, że Klient FARO otrzymuje ręczny system do skanowania laserowego, cechujący się wysoką efektywnością. 